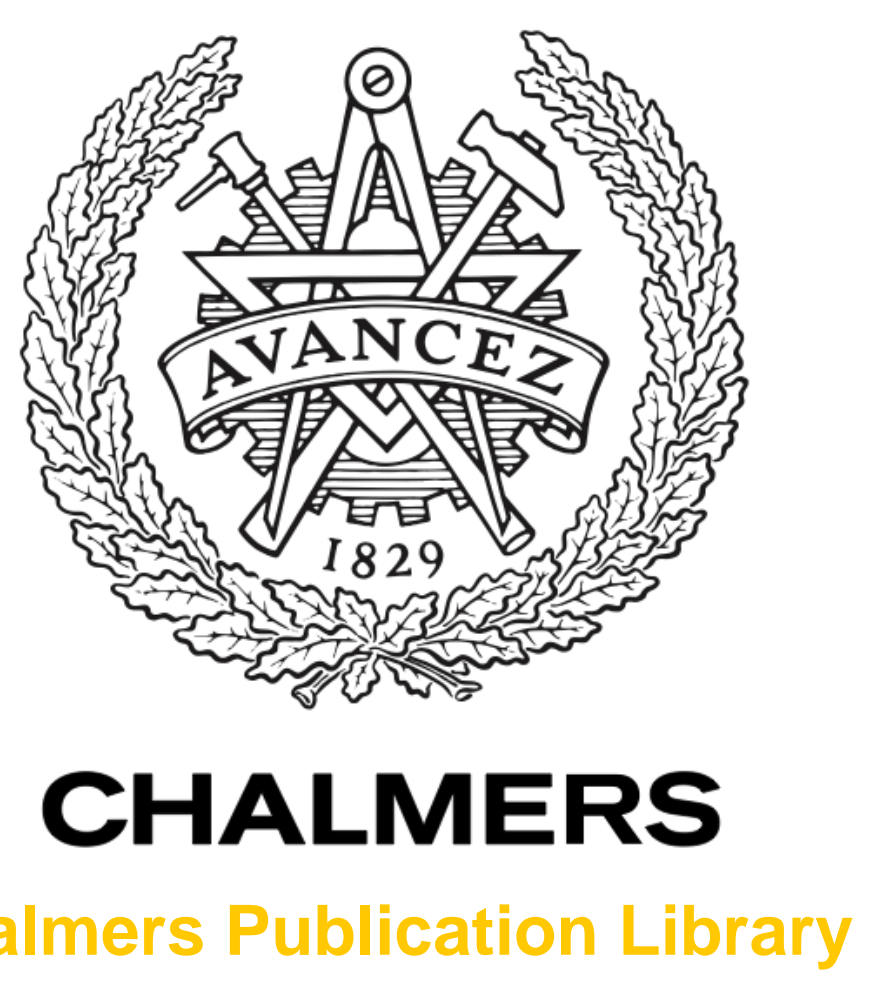

\title{
Rental price and sustainability ratings: which sustainability criteria are really paying back?
}

This document has been downloaded from Chalmers Publication Library (CPL). It is the author's version of a work that was accepted for publication in:

\section{Construction Management and Economics (ISSN: 0144-6193)}

Citation for the published paper:

Feige, A. ; Mcallister, P. ; Wallbaum, H. (2013) "Rental price and sustainability ratings: which sustainability criteria are really paying back?". Construction Management and

Economics, vol. 31(4), pp. 322-334.

http://dx.doi.org/10.1080/01446193.2013.769686

Downloaded from: http://publications.lib.chalmers.se/publication/179903

Notice: Changes introduced as a result of publishing processes such as copy-editing and formatting may not be reflected in this document. For a definitive version of this work, please refer to the published source. Please note that access to the published version might require a subscription. 


\section{Rental price and sustainability ratings - Which sustainability criteria are really paying back?}

Annika Feige (corresponding author)

Institute of Construction and Infrastructure Management

ETH Zurich

$\mathrm{CH}$ - 8093 Zürich

feige@ibi.baug.ethz.ch

Holger Wallbaum

Institute of Construction and Infrastructure Management

ETH Zurich

$\mathrm{CH}-8093$ Zürich

wallbaum@ibi.baug.ethz.ch

Patrick McAllister

Henley Business School

University of Reading

Real Estate \& Planning

UK - RG6 6UD

p.m.mcallister@henley.reading.ac.uk 


\begin{abstract}
Given the centrality of the price mechanism to resource allocation in market economies, the financial effects of sustainable construction have become an increasingly important empirical issue in the real estate industry. Drawing upon a sample of approximately 2,500 residential building units in Switzerland, this study assess the effects of buildings' sustainability of its rental price. In contrast to the vast majority of previous studies that have focussed on the price effects of ecolabels, this study investigates the effects of different sustainability criteria. We find that the sustainability of residential buildings positively affects their rental prices. Sustainable building characteristics, especially those which enhance the water efficiency, the health and comfort level and the building's safety and security, have significant positive price effects.
\end{abstract}

\title{
Key words
}

Sustainability, residential buildings, hedonic model, rent, sustainability evaluation 


\section{Introduction}

The financial returns from sustainable construction have become an increasingly important empirical issue for the real estate sector. In recent years, the added value or price benefits of so-called sustainable or green buildings as well as energy efficient buildings have generated a growing body of research. There are various reasons for this shift. A major factor has been the wide-ranging impact of the built environment with regard to its economic, ecological and social effects. In addition to indirect impacts, such as deforestation and the concomitant desertification and soil erosion, the eutrophication and acidification of water sources, biodiversity loss, and the generation/release of toxic substances and endocrine disruptors, the built environment directly increases environmental degradation by consuming $40 \%$ of the world's energy, $40 \%$ of the world's materials, $55 \%$ of wood cut for non-fuel use, and $12.2 \%$ of the total water used (see Kibert, 2008, Hoffman and Henn, 2008, Roodman et al., 1995, U.S. Green Building Council Research Committee, 2008, UNEP Sustainable Buildings \& Climate Initiative (SBCl), 2006).

According to Levine et al (2007), worldwide building-related $\mathrm{CO}_{2}$ emissions (including electricity usage) are expected to grow from 8.6 billion tons in 2004 to 11.4 billion tons in a low-growth scenario, or to as high as 15.6 billion tons by 2030 in a high growth scenario. This represents approximately $30 \%$ of global anthropogenic emissions. However, with proven and commercially available technologies, it is estimated that the energy consumption in both new and existing buildings can be reduced by $30-50 \%$ without significantly increasing investment costs (Cheng et al., 2008, Laustsen, 2008). These numbers demonstrate both the high impact of the building sector on the environment and the underlying potential to decelerate the increasing impact of this sector. 
Furthermore, the real estate industry faces growing pressure in terms of higher standards and stricter regulation concerning energy efficiency and sustainability. This development can be seen in several countries. In 2003, the European Union introduced the Energy Performance of Buildings Directive (EPBD). The directive requires the disclosure of energy performance of buildings. This has led to the implementation of national Energy Performance Certificates for residential buildings as well as commercial buildings. In Switzerland the EPBD initiative resulted in a building directive which requires that all new buildings must be "no heat energy buildings" from 2020 onwards.

In addition to the growth of state regulation, the growing awareness of sustainability among stakeholders of the building sector especially among users and owner, is a major incentive to build sustainably (Feige et al., 2011). At a corporate level, owning or occupying sustainable corporate buildings is often becoming part of companies' CSR strategies (Eichholtz et al., 2009). Usually these buildings are labelled as energy efficient, green or sustainable buildings (Figure 1). Nowadays, a variety of certification systems from around the world have emerged for buildings (Wallbaum and Hardziewski, 2011). Some of these are focused mainly on energy aspects like Energy Star (U.S) or Minergie (Switzerland). Some labels such as LEED (U.S.), BREEAM (UK), or Minergie Eco (Switzerland) also incorporate other environmental impacts and can be described as eco-labels.

Eco-certification schemes developed more recently tend to have a wider focus and contain several different sustainability attributes. These schemes provide independent verification of the sustainability of a building to tenants and 
investors. In addition to environmental aspects, they may also consider social and/or economic issues. The German DGNB-seal and the Swiss SGNI-seal are examples of such "sustainability labels".

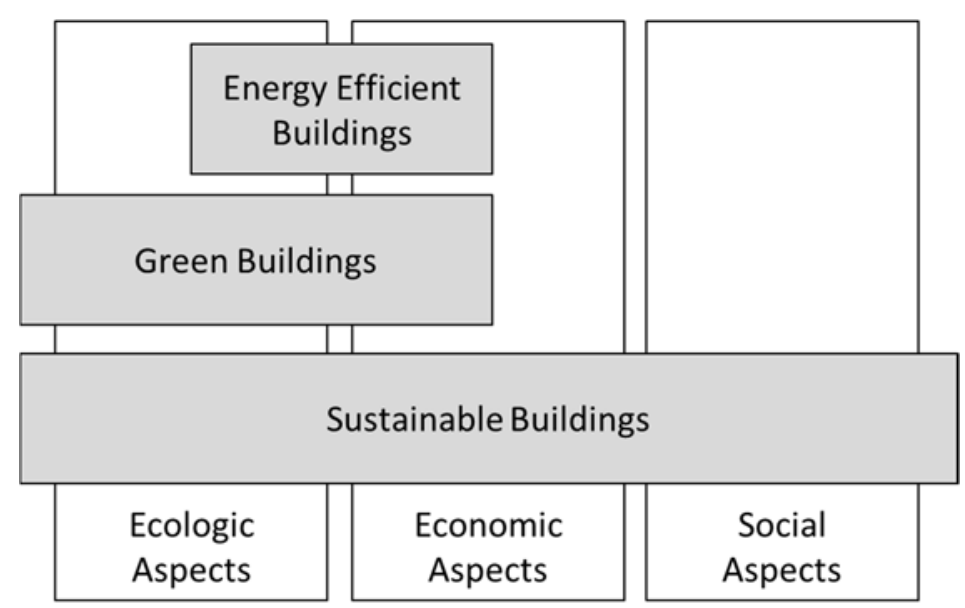

Figure 1: Building Types

Despite widely pronounced benefits of sustainable construction (image, running costs, risk, productivity etc.), the percentage of sustainable, green or energy efficient labelled buildings that have actually been built remains low. In 2011 there were about 24,000 LEED (Leadership in Energy and Environmental Design) certified residential and commercial buildings (LEED homepage Nov. 2011), an insignificant amount compared with the 1.8 million houses and 170000 commercial buildings built each year in the US (Hoffman and Henn, 2008). At the end of 2010, with 19421 energy-certified buildings in Switzerland the proportion of Minergie buildings represented only approximately $1 \%$ of the total building stock (Minergie homepage Nov. 2011, Meins et al., 2010, Steinemann et al., 2008).

Reasons for this situation are contested. They start with the general lack of information on the topic of sustainability, industry related communication shortfalls or cognitive or social barriers against sustainable development (Feige 
et al., 2011). Sustainable construction is often presumed as costly (Langdon, 2007). Higher planning costs or material costs for sustainable constructions are a major argument. Although life cycle analysis may show financial paybacks, the time span until these buildings break-even is often too far in the future and outside the horizon of investors (Meins et al., 2010). Further, life cycle costing is not still not common practice in the building sector (Nässén et al., 2008).

Misaligned incentives between investors and users can also add more conflict potential (Wallbaum and Meins, 2009). Leases structures are an important institutional factor. Although the investor or owner may incur the higher investment costs, where tenants pay for utilities, savings are mostly experienced by the occupier. Thus, at this point, sustainable features may not be profitable for investors unless there are other financial benefits, such as capital and rental value premiums, higher occupancy rates, reduced operational costs or a reduced risk premium. A significant proportion of real estate investors require evidence of financial returns if they are to invest in sustainable features. This question has generated a growing body of empirical research on the possible financial benefits of sustainable buildings. The broad aim of these studies is to estimate the relationship between increased sustainability and increased property value or increased prices. Research in this area is discussed below. 


\section{Related research}

As previously noted, the topic of the financial effects of sustainable construction or enhanced environmental performance of properties has been addressed by a number of researchers in the academic community and private sector. Research has mainly focussed on the effect of so-called eco-labels on property prices especially with regard to commercial buildings. A stylized fact emerging from this literature is that nearly all studies examining the effects of voluntary and compulsory environmental certification on the prices of real estate assets find a positive effect of superior environmental performance (usually measured by the presence of an eco-label). However, it is worth bearing a number of points in mind. Not all of the studies have been through a rigorous peer review process. More fundamentally, the vast majority of studies use hedonic analysis to attempt to isolate the effect on price of the environmental certificate. However, the omitted variable problem is pervasive in such studies. No studies have complete coverage of all the price determining variables. A central concern is that an ecocertificate is positively correlated with an unobserved variable e.g. quality of location, specification, construction, design etc. and that the effect of the unobserved variable is being mis-attributed to the eco-certificate. This problem has to be kept in mind while interpreting the results. However, given dynamic markets, up-to-date studies with better (in terms of scale and scope) data are still needed.

For US office markets, a number of revealed preference studies have emerged that broadly confirm occupiers' and investors' willingness to pay a premium for eco-labeled buildings. The majority of these studies have been conducted on the LEED Green Building Rating System and the Environmental Protection Agency's Energy Star system, which are two schemes that have been developed for the 
commercial real estate sector in the United States (see (Eichholtz et al., 2010, Fuerst and McAllister, 2011a, Miller et al., 2008, Reichardt et al., forthcoming, Wiley et al., 2010). However, it is important to bear in mind that, given the emerging nature of the market shift, sample sizes have typically been small. The results tend to be inconsistent due to differences in samples, econometric specification and data treatment. However, they are broadly consistent with positive rental premiums of $2-5 \%$ and higher sale price premiums.

In residential real estate markets, the first study investigating the price effects of mandatory eco-labelling was carried out by the Australian Bureau of Statistics in 2007. The study drew upon a database of residential sales in the Australian Capital Territory in the years 2005 (2385 transactions) and 2006 (2719 transactions). Using standard hedonic procedures to estimate the effect of Energy Efficiency Rating (EER) on house prices, they estimated five different model specifications. For 2005 sample, they estimate a premium of approximately $1 \%$ premium for every 0.5 increase in EER rating (EER ranges from 0-5). For 2006 sample, they estimate a premium of approximately $2 \%$ for every 0.5 increase in EER. For pooled sample, relative to zero rated house, they estimate premiums of 1.6\% (EER 1), 3\% (EER 2), 5.9\% (EER 3), 6.3\% ((EER 4) and $6.1 \%$ (EER 5). The explanatory power of the models is high and a large number of control variables for quality are included.

For mandatory eco-labels, for the Netherlands Brounen and Kok (2010) looked at the relationship between EPC rating and sale price for 18,190 residential sale prices in 2008. Compared to homes rated G, they estimate premiums of $12 \%$, $7 \%$ and $4 \%$ for $A, B$ and $C$ respectively. However, there are potential drawbacks in the study due to limited controls for building quality and location. Higher rated buildings may have been located in higher value locations within urban areas 
and/or have superior construction and/or specification. For instance, the only quality variable included in one of the models is condition and it is notable that, when it is included in the model, the estimated premiums drop substantially (Fuerst et al., 2011, Fuerst and McAllister, 2011a, Kok and Jennen, 2011).

In one of the few studies to find a price discount associated with superior environmental performance, Yoshida and Sugiura (2011) examined a sample of 34,862 condominium sales in 1,154 buildings certified under Tokyo Green Building Program. They estimate that condominiums in eco-labelled developments in Tokyo sell at a discount of 5.5\% compared to condominiums in non-labelled developments. When they investigate the effects of individual ecofeatures such as materials, planting and energy efficiency, they find a significantly negative effect of a high energy efficiency rating. They attribute this finding to the use of innovative or unusual technologies in a market where energy efficiency levels are already high. In Switzerland the price effect of energy certificates (Minergie $^{1}$ ) has also been analysed. In their market studies Salvi et al. (2008) estimated a $3.5-7 \%$ premium in transaction prices for Minergie labelled residential buildings.

All of the mentioned studies compare eco-certified buildings with standard (noncertified) buildings. However, there has been little investigation of the limited effects of the different facets of sustainability. In particular, the relative importance of intrinsic environmental performance and the pure brand-effect of

\footnotetext{
${ }^{1}$ Different types of Minergie certificates can be achieved depending on a building's actual energy consumption. The regular Minergie-Standard requires that general energy consumption must not to be higher than $75 \%$ of that of average buildings. Minergie-P defines buildings with very low energy consumption. Minergie- ECO adds ecological requirements such as indoor air quality, noise protection, etc. to the regular MinergieRequirements.
} 
the eco-label are debated. This study looks at the price effects of different facets of sustainability performance for residential building units which have been measured according to a list of sustainability criteria. The price effect of the rating of each defined and evaluated criterion is then estimated using hedonic regression procedures.

\section{Data and method}

3.1 Methodology hedonic model/ econometric model

In real estate research, hedonic regression modelling is a standard methodology for evaluating price or value determinants. Hedonic modelling has a long history, dating back to the 1920 s, where it was used to examine the value of farmland (Haas, 1922b, Haas, 1922a, Wallace, 1926). At a later stage, the microeconomic foundation for estimating the value of utility-generating characteristics and for nonlinear hedonic pricing was laid (Rosen, 1974, Lancaster, 1966, Sirmans et al., 2005).

According to Rosen (1974), with hedonic modelling a product is completely described by a vector of objective measured characteristics. Hence, hedonic prices are defined as the implicit prices of attributes. Generally the hedonic model takes the following form:

$$
\text { Price }=f \text { (Physical Characteristics, Other Factors) }
$$

In real estate research this has generally analysed the price or value of a building or unit as a function of its physical and economic characteristics like square footage, age, location etc., and other factors such as tax class. 
In this analysis, in addition to the standard locational and physical characteristics, a range of sustainability criteria are included in the model so that their effect on rental price can be isolated and measured.

The selected log-linear hedonic model has the following form:

$$
\ln \mathrm{R}_{i}=\alpha_{\mathrm{i}}+\beta x_{\mathrm{i}}+\varepsilon_{\mathrm{i}}
$$

The log-linear specification of the hedonic model mitigates the effect of extreme values and also makes it possible to interpret the coefficients in average percentage premiums. The hedonic model has been derived to explain the influencing factors for the achieved rental price. In the model, $R_{i}$ is the natural log of the effective market rent per square metre in the respective building unit. The variable $x_{\mathrm{i}}$ is a vector of the natural log of different explanatory characteristics, such as physical characteristics or sustainability criteria. $\alpha$ and $\beta$ stand for the respective vectors of parameters to be estimated. The $\varepsilon$ variable is a random error term of the model.

\subsection{Data}

Data from five different portfolio owners in Switzerland (one public institution and four institutional investors) is used. In total, the data set is comprised of property information from around 450 buildings, which contains more than 10,000 rental units spread all over Switzerland. Different types of properties are included in the portfolios: office, retail and residential units. With more than 9000 units, residential buildings represented by far the biggest share within the whole portfolio set. This building type has been chosen for the analysis. The reference year for the data included is 2009 as this was the year with the highest data availability. Due to missing data for some variables, the sample is reduced to 2453 units in the regression analysis. 
Detailed information on the buildings has been obtained from the property owners. In addition, the buildings have been evaluated according to a range of financial and sustainability criteria. This has been conducted by independent private consultancies or the portfolio holders themselves according to standardised methods and, for the sustainability evaluation, using the defined list of criteria (Table A.1).

As mentioned, the respective buildings are located all over Switzerland. The range of rental prices within Switzerland is quite high, depending on the location. Thus, controlling for location effects is extremely important. Significant differences exist between cities and urban areas, but also the intra-urban variations in location can have major effects. Taking this into consideration, the locations of all properties have been rated. The exact address with respective micro and macro criteria is included in this location rating. The rating ranges from 1 to 7 , with 1 as the best and 7 as the worst rating. The rating was developed by researchers from the University of Zurich together with the ZKB (Zuericher Kantonalbank) and has already been used previously for internal corporate purposes as well as in previous research (Salvi et al., 2008, Salvi et al., 2004). The location factor incorporates micro and macro aspects such as tax rate, urban district, centrality, view, distance to local centres etc.

\subsection{Sustainability rating}

All the buildings in the sample have been evaluated by private consultancies according to 36 different sustainability indicators. The indicators have been grouped in sub-indicators (second level) and further in sustainability features (first level). In total, there are five different sustainability features, namely flexibility, 
energy and water consumption, accessibility and mobility, safety and security and health and comfort (Table 2). The list of indicators can be found in the Appendix.

Table 2: Short List of Indicators

\begin{tabular}{|c|c|c|}
\hline First Level & Second Level & Third Level \\
\hline Sustainability features & Sub-indicators & Indicators \\
\hline 1. Flexibility & $\begin{array}{ll}1 & \text { Flexibility of use } \\
2 & \text { Adaptability to users }\end{array}$ & \multirow{5}{*}{36 Indicators } \\
\hline $\begin{array}{l}\text { 2. Energy and Water } \\
\text { Efficiency }\end{array}$ & $\begin{array}{ll}3 & \text { Energy } \\
4 & \text { Water }\end{array}$ & \\
\hline $\begin{array}{l}\text { 3. Accessibility and } \\
\text { Mobility }\end{array}$ & $\begin{array}{ll}5 & \text { Public Transport } \\
6 & \text { Non-motorized vehicles } \\
7 & \text { Accessibility }\end{array}$ & \\
\hline 4. Safety and Security & $\begin{array}{ll}8 & \text { Location regarding natural hazards } \\
9 & \text { Building safety and security } \\
& \text { measures }\end{array}$ & \\
\hline 5. Health and Comfort & 10 Health and Comfort & \\
\hline
\end{tabular}

The set of indicators was derived in 2008 by an expert panel containing valuers, property investors, real estate and construction academics in Switzerland.

The 36 indicators have been rated as either

$-1=$ the building does not fulfil the criteria of this sustainability indicator at all (below common standards and norms),

$0=$ the building fulfils common building standards and norms,

$+1=$ the building fulfils the criteria of this sustainability indicator (exceeds common standards and norms). 
Out of these indicator ratings, the rating of the ten sub-indicators and further the five sustainability features was developed. Combining the indicator rating with an individual weight for the indicator resulted in the sustainability rating on subindicator level and on the level of the five sustainability features. The weight of each indicator has also been assigned by the expert panel. The results on the first and second level range from $-1,-0.9,-0.8 \ldots$ to $+0.8,+0.9,+1$ in decimal steps having -1 as the worst and +1 as the best sustainability rating.

For the hedonic model, the effective rent per square metre of the unit in 2009 was chosen as the dependent variable. The effective rent is defined as the net rent per month. Hence, the vacancy rate of the units is already considered in the rental payment. Furthermore, several physical criteria have been considered in the analysis. They are all listed in the descriptive statistics in Table 1. These include frequently included characteristics in hedonic modelling, such as size, age, number of stories, number of rooms and location factors (Sirmans et al., 2005).

Although it was possible to derive a large set of property level information, there were still some gaps in the data causing potential omitted variable bias. One of the main problems is the absence of building quality data. In general, the definition and valuation of a building's quality is rather difficult. It tends to involve some composite of characteristics, including condition, location, internal specification, design, age, construction and facilities, among others. Often buildings are rated using some simple heuristic measures such as prime/secondary, A/B etc. Even though some of the quality characteristics are included in the study, not all are. Omitted variable problems, however, is a standard limitation of cross-sectional hedonic studies and are acknowledged here. 
Table 1: Descriptive Statistics

\begin{tabular}{|c|c|c|c|c|c|}
\hline & $\mathrm{N}$ & Mean & Median & Min & Max \\
\hline Location factor total & 9112 & 3.12 & 3.00 & 1 & 7 \\
\hline Year constructed & 9035 & 1972 & 1968 & 1712 & 2010 \\
\hline $\begin{array}{l}\text { Number of Units within } \\
\text { the building }\end{array}$ & 4909 & 54 & 46 & 1 & 164 \\
\hline Number of Floors & 8232 & 5.14 & 5 & 2 & 15 \\
\hline $\begin{array}{l}\text { Total space (square } \\
\text { metres) }\end{array}$ & 7859 & 4426 & 3866 & 100 & 12095 \\
\hline Elevator (yes, no) & 7601 & 0.56 & 1 & 0 & 1 \\
\hline Parking spaces (yes, no) & 9086 & 0.88 & 1 & 0 & 1 \\
\hline Flexibility & 8980 & 0.012 & .06 & -.88 & 0.94 \\
\hline $\begin{array}{l}\text { Energy and Water } \\
\text { Efficiency }\end{array}$ & 9112 & -0.52 & -0.55 & -1.00 & 0.30 \\
\hline $\begin{array}{l}\text { Accessibility and } \\
\text { Mobility }\end{array}$ & 9112 & 0.26 & 0.22 & -0.69 & 0.92 \\
\hline Safety and Security & 9112 & 0.42 & 0.50 & -0.83 & 1.00 \\
\hline Health and Comfort & 9112 & -0.21 & -0.25 & -1.00 & 1.00 \\
\hline Number of floors & 8232 & 5.1 & 5 & 2 & 15 \\
\hline $\begin{array}{l}\text { Size of unit (square } \\
\text { metres) }\end{array}$ & 7811 & 82 & 79 & 11.00 & 439.00 \\
\hline $\begin{array}{l}\text { Number of rooms per } \\
\text { unit }\end{array}$ & 9097 & 3.4 & 3.5 & 1.0 & 9.0 \\
\hline Floor level unit & 3835 & 2.2 & 2 & 0 & 15 \\
\hline Balcony (yes, no) & 4921 & 0.58 & 1 & 0 & 1 \\
\hline Lease Start (year) & 8328 & 2002 & 2006 & 1958 & 2011 \\
\hline $\begin{array}{l}\text { Effective Rent per Unit } \\
\text { and } \mathrm{m}^{2} \text { in } 2009 \text { (Swiss } \\
\text { Francs) }\end{array}$ & 7722 & 17.09 & 16.63 & 0.82 & 72.94 \\
\hline Value (Swiss Francs) & 7471 & $\begin{array}{r}131462 \\
86\end{array}$ & $\begin{array}{r}102100 \\
00\end{array}$ & 230000 & $\begin{array}{r}495200 \\
00\end{array}$ \\
\hline
\end{tabular}


One important modelling issue in this study is whether the analysis should take place at a building or at a rental unit level. In other studies, the average rental price or value for the whole building has been used. This is usually due to a lack of information at the unit level. For this study, detailed information is available at the unit level. Since, a number of indicators included in the model are at the building level e.g. location or the sustainability features, blending these building characteristics with unit level data raises some methodological issues. Given that buildings have varying numbers of building units, and therefore, different shares of rental units in the whole portfolio, this approach could have led to biased estimates. To control these effects, the hedonic model has also been tested using random sampling. Hence, from each of the buildings, only one randomly chosen rental unit has been included. Reassuringly, this model provides very similar results as the one using the complete data set (See Appendix).

\section{Results and Discussion}

The results of the analysis are shown in Table 3. Most of the results are expected. As shown in Table 3, lease start, unit size and location are significant determinants of the rental price. Not surprisingly, compared to older lease contracts, the more recent lease contracts have higher rental prices. This is understandable since the rental price for residential units is continuously rising in Switzerland. Even though the rental price is often linked to a rental price index, and thus following yearly changes, the existing duration of the contract defines the bases of the price. The results in Table 3 show the difference in this base price depending on the lease start. 
Table 3:

Hedonic Regression Results

Dependent Variable: Effective Rent per m2 2009 (log)

Model 1

Model 2

(Constant)

Coefficient

Coefficient

Lease Start

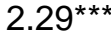

$1.97^{\star \star \star}$

$0.21^{* * *}$

$0.20^{\star \star \star}$

Number of Floors (log)

$-0.17^{\star * *}$

$-0.15^{\star \star *}$

Square metre unit (log)

$-0.39 * \star \star$

$-0.36^{\star \star \star}$

Number of Rooms within Unit (log)

$0.09^{* \star *}$

$0.08^{\star * *}$

Floor Level of Unit (log)

$0.05^{\star \star \star}$

$0.05^{\star \star \star}$

Location Rating 1

Omitted

Omitted

Location Rating 2

$-0.22^{\star \star \star}$

$-0.18^{\star \star *}$

Location Rating 3

$-0.32^{\star \star \star}$

$-0.32^{\star \star \star}$

Location Rating 4

$-0.38^{\star \star \star}$

$-0.41^{\star \star *}$

Location Rating 5

$-0.43^{\star \star \star}$

$-0.36^{\star \star *}$

Location Rating 7

$-0.72^{* * *}$

$-0.67^{\star \star *}$

2010-2000

Omitted

Omitted

1999-1990

$-0.03^{\star * \star}$

$0.06^{\star \star *}$

1989-1980

$-0.11^{\star \star \star}$

$-0.07^{\star \star \star}$

1979-1970

$-0.12^{\star \star *}$

$-0.01$

1969-1960

$-0.15^{\star \star \star}$

$-0.11^{\star \star \star}$

1959-1950

$-0.05^{\star *}$

$-0.09 * * *$

1939-1930

$-0.57^{\star \star \star}$

$-0.57^{\star \star \star}$

$<1930$

0.0

$0.17^{\star \star \star}$

Flexibility

Flexibility of use

$-0.01$

Adaptability to users

$0.05^{\star \star \star}$

$-0.04^{\star \star \star}$

Energy and Water Efficiency

$0.11 * * *$

Energy efficiency

$-0.29^{\star \star \star}$

Water efficiency

$0.12^{\star \star \star}$

Accessibility and Mobility

$-0.04^{\star * \star}$

Public transport

$-0.001$

Non-motorised vehicles

$-0.03^{\star \star *}$

Accessibility

$0.08^{\star \star \star}$

Safety and Security

$0.09 * * *$

Location regarding natural hazards

$0.01^{* *}$

$0.07^{\star \star \star}$

Building safety and security measures

$0.12^{\star * \star}$

Health and Comfort

$0.09 * * \star$

$\mathrm{N}=2453$

$\mathrm{N}=2453$

$\mathrm{R} 2=0.70$

$\mathrm{R} 2=0.66$

* significant at $10 \%$ Level ${ }^{* \star}$ significant at $5 \%$ Level ${ }^{* \star *}$ significant at $1 \%$ Level 
Regarding unit size, the analysis shows the smaller the flat is, the higher the rental price per square metre. This is also not surprising. The location indicator shows the expected results. The model estimates that, rental prices decline steadily as quality of location declines. As already explained, the location indicator varies from 1-7, with 1 as the best and 7 as the worst location rating ${ }^{2}$. For this analysis, location dummies have been assigned. Within the analysis each location group is compared to the reference group (Location $1=$ Best location). The coefficients show how much the effective rent per square metre in each location group differs in comparison to the reference group.

Further significant factors are floor level of the respective unit, total number of floors within the building, number of rooms within the unit and building age. The model estimates that the rental price is negatively associated with building height. However, the rental units on the higher floors show higher prices. The rental price per square metre also rises as the number of rooms increases. Age also has a significant influence. With $2010-2000$ as the reference period, older buildings have comparably lower rental prices. In comparison to the other age groups, buildings from the 1930s, 1960s and 1970s have the lowest unit price. However, the results from the oldest age classes cannot really be interpreted since the number of buildings within these groups is very low. ${ }^{3}$ The described results are in line with other mentioned studies (Brounen and Kok, 2010, Brounen et al., 2009, Chegut et al., 2010, Eichholtz et al., 2010, Fuerst and McAllister, 2009, Fuerst and McAllister, 2011b, Fuerst and McAllister, 2011a, Miller et al., 2008, Pivo and Mc Namara, 2005, Reed, 2008).

\footnotetext{
${ }^{2}$ In this analysis the category location 6 is not included since no buildings have been evaluated with a location rating of 6 .

${ }^{3}$ In this analysis the category 1949-1940 has been excluded due to the lack of data availability.
} 
Turning to the variables of interest, for the sustainability features the results are diverse. Four out of five of the sustainability features show a significant influence on the rental price. Three of them have a positive influence: energy and water efficiency, safety and security and health and comfort. The analysis shows that the higher the rating of those sustainability features, the higher the rent. With around 1\% change in price per 0.1 difference in the sustainability score, the most influential factor is "energy and water efficiency". This means if the sustainability rating of the sustainability feature improves in one decimal place (e.g. from +0.5 to +0.6$)$ the rental price rises by $1 \%$. The influence of the other two factors is slightly smaller. The increase by 0.1 points in the sustainability ratings of "safety and security" and "health and comfort" leads to $0.85 \%$ higher rental price.

Surprisingly, all else equal, the model estimates that a strong score in terms of accessibility and mobility has a negative effect on rental price. In addition, flexibility has no statistically significant effect on price. To further investigate the reasons for these results, a second model has been estimated using the subindicators level of the sustainability evaluation. Hence, ten different sustainability indicators are evaluated in this second model.

The sub-indicators of the sustainability feature "accessibility and mobility" are: public transport, non-motorised vehicles and accessibility, which describes the distances to local centres, etc. Out of these three indicators, only the indicator for non-motorised vehicles has a negative effect on the price. A possible explanation for this could be the definition of the criteria for the non-motorised vehicles indicator - it is essentially a measure of the availability of bicycle parking spaces. In Switzerland, the prime locations for buildings are in the city centres which tend 
to be dominated by older building structures with narrow streets and few open spaces. The buildings are directly linked to each other so that additional parking spaces for bicycles tend not to be available. Hence the most expensive locations often have poor bicycle facilities. However, being situated close to the regional centres has a positive price effect - as the sub-indicator "accessibility" shows.

For the second sustainability feature "flexibility", the two sub-indicators have been analysed. While flexibility of use has a significant positive influence, adaptability to user demands still has a negative impact on the rental price. Indicators of adaptability of user demands are for example the aspect of wheelchair accessibility or usability of outside space. Rental units with these characteristics are often on ground floor level, where rental prices are usually low (see variable "floor level of unit").

An important, but unexpected, result is the estimate for energy efficiency. The model shows that energy efficiency has a significantly negative impact on rental prices. This suggests that less energy efficient buildings achieve a higher rental price. Whilst this finding is contrary to other studies which have shown a price premium for energy labelling and hence energy efficient buildings (Brounen and Kok, 2010, Fuerst and McAllister, 2011b) it is in line with the finding by Yoshida and Saigura (2011). The explanation for this surprising result is likely to lie in the typical Swiss lease structure for residential buildings. Building owners in Switzerland usually charge a defined rent to their tenants (gross rent) which includes energy costs. Building owners are then responsible for payment of energy costs. However, if tenants consume more (or less) energy than previously estimated, they have to pay an additional fee to the building owner (or get a refund from the building owner) at the end of the period. The results are 
consistent with owners of less energy efficient buildings charging higher rents to incorporate expected higher energy costs.

Overall, the results for the indicators are mostly in line with expectations and consistent with previous research on price premiums for sustainable or green buildings. However, the analysis shows that not all sustainability indicators that have been assessed in this study result in a price premium. Especially in comparison to other studies which look solely at the premium for certifications. This is an interesting finding since the analysis shows that not all of the criteria included in building certification metrics seem to have a price impact. It is building characteristics, especially those which relate to water efficiency or health and comfort improvement, result in an increased rental price. Other criteria like building flexibility or safety as they are defined in sustainability evaluation seem to be less important or not significant in terms of price effects.

\section{Conclusion}

In market economies, the pricing mechanism is the main means by which economic resources are allocated. From the perspective of reducing carbon emissions from the building stock, many market participants require price incentives to adopt sustainable technologies and practices. Further, in terms of policy design it is important for policy makers to have robust evidence of whether sufficient price incentives are present or working as expected. This paper provides the some initial evidence on how different sustainability criteria affect rental prices of residential buildings. Given the numerous dimensions of sustainability, it is important that owners and developers have some 
understanding of the relative financial benefits from allocating resources to these different dimensions.

Having a large set of building information available, we utilise the residential sector in Switzerland as a laboratory using data provided by large portfolio owners. In general, we find that the sustainability of residential buildings positively affects their rental prices. Sustainable building characteristics, especially those which enhance the water efficiency, the health and comfort level and the building's safety and security have significant positive price effects. Conversely, some sustainability characteristics have no significant effect on the rental price or and even have an apparent negative influence.

In particular, the finding of a negative association with energy efficiency rating and price is, at first sight, surprising. The most likely explanation is that in Switzerland, owners tend to be responsible for payment of energy costs to energy providers and can recover them from tenants effectively 'bundling' of energy costs and rent into a single charge. As a result, owners appear to be charging higher levels of 'rent' for energy inefficient buildings. Such lease structures are providing little incentives for landlords to conserve energy and providing weak and noisy price signals to energy consumers.

This study, similar to the large majority of previous studies, provides a static cross-sectional estimate of price effects. Like most previous studies, the data are consistent with a positive association between a number of sustainable features and (rental) prices. However, it is important to acknowledge that the price effects of various sustainability attributes are likely to be dynamic and variable between assets and markets. Ultimately, they are a function of a specific set of supply and demand conditions. A major area of future research is to obtain time series of the 
financial, sustainability and asset attributes required to conduct research dynamic price effects and sufficiently large data sets to assess whether there are significant differences in price effects between markets and assets.

\section{Acknowledgement}

This study was supported financially by Ernst Basler \& Partner and the Holcim Foundation for Sustainable Construction. We gratefully acknowledge this support. Furthermore, we would like to thank the Züricher Kantonalbank for assisting us with the necessary location ratings and the five portfolio owners who kindly provided all the required building information. Special thanks go to Erika Meins for the project lead and Markus Gaebel, whose help with the data preparation and continuous feedback are greatly appreciated.

\section{$7 \quad$ Appendix}

Table 1: Full list Sustainability indicators

\begin{tabular}{|c|c|}
\hline $\begin{array}{l}\text { Sustainability } \\
\text { features }\end{array}$ & Sub-indicators with indicators \\
\hline 1.Flexibility & $\begin{array}{l}\text { 1.1 Flexibility of use } \\
\text { 1.1.1 Floor plan } \\
\text { 1.1.2 Storey height } \\
\text { 1.1.3 Accessibility, reserve capacity, and wiring / pipes / building } \\
\text { services } \\
\text { 1.2 Adaptability to users } \\
\text { 1.2.1 Wheelchair accessibility } \\
\text { 1.2.2 Flexibility of kitchen layout } \\
\text { 1.2.3 Room for storage of walker / pram } \\
\text { 1.2.4 Balcony } \\
\text { 1.2.5 Usability of outside space }\end{array}$ \\
\hline
\end{tabular}




\begin{tabular}{|c|c|}
\hline $\begin{array}{l}\text { 2. Energy and } \\
\text { Water Efficiency }\end{array}$ & $\begin{array}{l}\text { 2.1 Energy } \\
\text { 2.1.1 Energy consumption } \\
\text { 2.1.2 Locally produced renewable energy } \\
\text { 2.2 Water } \\
\text { 2.2.1 Water use } \\
\text { 2.2.2 Wastewater disposal } \\
\text { 2.2.3 Rainwater use }\end{array}$ \\
\hline $\begin{array}{l}\text { 3. Accessibility } \\
\text { and Mobility }\end{array}$ & $\begin{array}{l}\text { 3.1 Public Transport } \\
\text { 3.1.1 Good connection to public transport } \\
\text { 3.2 Non-motorized vehicles } \\
\text { 3.2.1 Bicycle parking near the building } \\
\text { 3.3 Accessibility } \\
\text { 3.3.1 Distance to local / regional centre } \\
\text { 3.3.2 Distance to shops } \\
\text { 3.3.3 Distance to local recreation area }\end{array}$ \\
\hline $\begin{array}{l}\text { 4. Safety and } \\
\text { Security }\end{array}$ & $\begin{array}{l}\text { 4.1 Location regarding natural hazards } \\
\text { 4.1.1 Location regarding natural hazards (Risk of floods, } \\
\text { avalanches, landslides, collapse) } \\
\text { 4.2 Building safety and security measures } \\
\text { 4.2.1 Object related safety and security measures } \\
\text { 4.2.2 Safety and security measures related to people }\end{array}$ \\
\hline $\begin{array}{l}\text { 5. Health and } \\
\text { Comfort }\end{array}$ & $\begin{array}{l}\text { 5.1 Health and Comfort } \\
\text { 5.1.1 Inside air quality } \\
\text { 5.1.2 Noise exposure } \\
\text { 5.1.3 Sufficient natural light } \\
\text { 5.1.4 Radiation exposure } \\
\text { 5.1.5 Ecological construction materials }\end{array}$ \\
\hline
\end{tabular}

Table 2: Hedonic Regression Results (Estimation generated by random selected units)

$\begin{array}{ll}\text { Dependent Variable: Effective Rent per m2 } 2009(\log ) & \text { Coefficient } \\ \text { (Constant) } & 0.35 \\ \text { Lease Start } & 0.34^{\star \star \star} \\ \text { Number of Floors (log) } & -0.14^{\star \star} \\ \text { Square metre unit (log) } & -0.28^{\star \star} \\ \text { Number of Rooms within Unit (log) } & 0.04\end{array}$




$\begin{array}{ll}\text { Floor Level of Unit (log) } & 0.07^{\star \star} \\ \text { Location } 1 & \text { Omitted } \\ \text { Location } 2 & -0.30^{\star \star \star} \\ \text { Location } 3 & -0.40^{\star \star \star} \\ \text { Location } 4 & -0.49^{\star \star \star} \\ \text { Location } 5 & -0.54^{\star \star \star} \\ \text { Location } 7 & -0.86^{\star \star \star} \\ \text { 2010-2000 } & \text { Omitted } \\ \text { 1999-1990 } & -0.07 \\ \text { 1989-1980 } & -0.13^{\star} \\ \text { 1979-1970 } & -0.20^{\star \star} \\ \text { 1969-1960 } & -0.202^{\star \star \star} \\ \text { 1959-1950 } & -0.03 \\ \text { 1939-1930 } & -0.73^{\star \star \star} \\ <1930 & -0.09 \\ \text { Flexibility } & -0.09 \\ \text { Energy and Water Dependency } & 0.13 \\ \text { Accessibility and Mobility } & -0.13^{\star \star} \\ \text { Safety and Security } & 0.09^{\star} \\ \text { Health and Comfort } & 0.07 \\ & \mathrm{~N}=137 \\ \text { Legend * significant at 10\% Level ** significant at 5\% Level } & \star \mathrm{R}^{2}=0.64 \\ \end{array}$

\section{References}

BROUNEN, D. \& KOK, N. 2010. On the economics of energy labels in the housing market. Journal of Environmental Economics and Management, in press.

BROUNEN, D., KOK, N. \& MENNE, J. 2009. Energy Performance Certification in the Housing Market - Implementation and valuation in the European Union.

CHEGUT, A., EICHHOLTZ, P. \& KOK, N. 2010. A GLOBAL PERSPECTIVE ON THE VALUE OF GREEN BUILDINGS. 17th Annual European Real Estate Society Conference. Milan. 
CHENG, C., POUFFARY, S., SVENNINGSEN, N. \& CALLAWAY, M. 2008. The Kyoto Protocol, the Clean Development Mechanism and the building and construction sector - A report for the UNEP Sustainable Buildings and Construction Initiative. In: PROGRAMME, U. N. E. (ed.). Paris.

EICHHOLTZ, P., KOK, N. \& QUIGLEY, J. M. 2009. Why companies rent green: CSR and the role of real estate. ERES. Stockholm.

EICHHOLTZ, P., KOK, N. \& QUIGLEY, J. M. 2010. Doing Well by Doing Good? Green Office Buildings. American Economic Review, 100, 2492-2509.

FEIGE, A., WALLBAUM, H. \& KRANK, S. 2011. Harnessing stakeholder motivation: towards a Swiss sustainable building sector. Building Research \& Information, 39, 504-517.

FUERST, F. \& MCALLISTER, P. 2009. New Evidence on Green Building Rent and Price Premium. Annual Meeting of the American real Estate Society. Monterey.

FUERST, F. \& MCALLISTER, P. 2011a. Eco-labeling in commercial office markets: Do LEED and Energy Star offices obtain multiple premiums? Ecological Economics, 70, 1220-1230.

FUERST, F. \& MCALLISTER, P. 2011b. Green Noise or Green Value? Measuring the Effects of Environmental Certification on Office Values. Real Estate Economics, 39, 45-69.

FUERST, F., MCALLISTER, P., VAN DE WETERING, J. \& WYATT, P. 2011. Measuring the financial performance of green buildings in the UK commercial property market: Addressing the data issues. Journal of Financial Management of Property and Construction, 16, 163 - 185.

HAAS, G. C. 1922a. Sales Prices as a Basis for Farm Land Appraisal. Technical Bulletin 9. St. Paul. Minnesota: The University of Minnesota Agricultural Experiment Station. 
HAAS, G. C. 1922b. A statistical Analysis of Farm Sales in Blue Earth County, Minnesota, as a Basis for Farm Land Appraisal Master Thesis, The University of Minnesota.

HOFFMAN, A. J. \& HENN, R. 2008. Overcoming the social and psychological barriers to green building. Organization \& Environment, 21, 390-419.

KIBERT, C. J. 2008. Sustainable construction: Green building design and delivery, New Jersey, John Wiley \& Sons Inc.

KOK, N. \& JENNEN, M. 2011. The Value of Energy Labels in the European Office Market. Maastricht.

LANCASTER, K. J. 1966. A New Approach to Consumer Theory. Journal of Political Economy, 74, 132-157.

LANGDON, D. 2007. The costs \& benefits of achieving green buildings. Australia. LAUSTSEN, J. 2008. Energy Efficiency Requirements in Building Codes, Energy Efficiency Policies for New Buildings. Paris: IEA.

LEVINE, M., ÜRGE-VORSATZ, D., BLOK, K., GENG, L., HARVEY, D., LANG, S., LEVERMORE, G., MONGAMELI MEHLWANA, A., MIRASGEDIS, S., NOVIKOVA, A., RILLING, J. \& YOSHINO, H. 2007. Residential and commercial buildings. In: METZ, B., DAVIDSON, O. R., BOSCH, P. R., DAVE, R. \& MEYER, L. A. (eds.) Climate Change 2007: Mitigation. Contribution of Working Group III to the Fourth Assessment Report of the Intergovernmental Panel on Climate Change. Cambridge, UK and New York, USA.

MEINS, E., WALLBAUM, H., HARDZIEWSKI, R. \& FEIGE, A. 2010.

Sustainability and property valuation: a risk-based approach. Building Research \& Information, 38, 280-300.

MILLER, N., SPIVEY, J. \& FLORANCE, A. 2008. Does Green Pay off? Journal of Real Estate Portfolio Management, 14, 385-399. 
NÄSSÉN, J., SPREI, F. \& HOLMBERG, J. 2008. Stagnating energy efficiency in the Swedish building sector-Economic and organisational explanations. Energy Policy, 36, 3814-3822.

PIVO, G. \& MC NAMARA, P. 2005. Responsible Property Investing. International Real Estate Review, 8, 128-143.

REED, R. G. 2008. Encouraging the uptake of sustainable buildings and the role of the property valuer. 8 .

REICHARDT, A., FUERST, F., ROTTKE, N. B. \& ZIETZ, J. forthcoming. The business case of sustainable building certification: A panel data approach. Journal of Real Estate Research.

ROODMAN, D. M., LENSSEN, N. K. \& PETERSON, J. A. 1995. A Building Revolution: How Ecology and Health Concerns Are Transforming Construction, Washington, Worldwatch.

ROSEN, S. 1974. Hedonic Prices and Implicit Markets: Product Differentiation in Pure Competition. Journal of Political Economy, 82, 34-55.

SALVI, M., HOREJÁJOVÁ, A. \& MÜRI, R. 2008. Minergie macht sich bezahlt. Zürich: CCRS und Zürcher Kantonalbank.

SALVI, M., SCHELLENBAUER, P. \& SCHMIDT, H. 2004. Preise, Mieten und Renditen. Der Immobilienmarkt transparent gemacht.

SIRMANS, S. G., MACPHERSON, D. A. \& ZIETZ, E. N. 2005. The Composition of Hedonic Pricing Models. Journal of Real Estate Literature, 13, 3-43.

STEINEMANN, M., MEINS, E. \& GUYER, M. 2008. Dokumentation zum Konsum Report Schweiz. Zürich

U.S. GREEN BUILDING COUNCIL RESEARCH COMMITTEE 2008. A National Green Building Research Agenda. Washington. 
UNEP SUSTAINABLE BUILDINGS \& CLIMATE INITIATIVE (SBCI) 2006.

Sustainable Building and Construction Initiative, Information note. Paris:

UNEP, Division of Technology, Industry and Economics.

WALLACE, H. A. 1926. Comparative Farmland Values in lowa. Journal of Land and Public Utility Economics, 2, 385-392.

WALLBAUM, H. \& HARDZIEWSKI, R. 2011. Minergie und die anderen Vergleich von vier Labels. TEC21 - Fachzeitschrift für Architektur, Ingenieurwesen und Umwelt, 47, 32-39.

WALLBAUM, H. \& MEINS, E. 2009. Nicht-nachhaltiges Planen, Bauen und Betrieben - Aus guten Gründen (noch) die Praxis in der Bauwirtschaft? Bauingenieur, 291-304.

WILEY, J., BENEFIELD, J. \& JOHNSON, K. 2010. Green Design and the Market for Commercial Office Space. The Journal of Real Estate Finance and Economics, 41, 228-243.

YOSHIDA, J. \& SUGIURA, A. Which "Greenness" is Valued? Evidence from Green Condominiums in Tokyo. Green Building Finance and Investments: Practice, Policy and Research 2011 Maastricht. 